\title{
Is it really difficult to produce correct th (/ð / and / $/$ /) sounds in English for EFL learners? A case study in Northern Cyprus
}

\author{
Halil Ercan ${ }^{a *}$ (iD), Naciye Kunt ${ }^{b}$ \\ ${ }^{a}$ Final International University, Toroslar Avenue, No:6, 99370, Catalkoy, Kyrenia via Mersin 10 Turkey, TRNC \\ ${ }^{b}$ Eastern Mediterranean University, 99628, Famagusta, Mersin 10 Turkey, TRNC
}

\author{
APA Citation: \\ Ercan, H, \& Kunt, N. (2019). Is it really difficult to produce correct th (// / and / $/$ /) sounds in English for EFL learners? A case study in \\ Northern Cyprus: Journal of Language and Linguistic Studies, 15(3), 926-936. \\ Submission Date: 14/03/19 \\ Acceptance Date: 06/07/19
}

\begin{abstract}
This study investigated how th (/ð/ and / $/$ /) sounds could be improved if opportunities were provided to EFL learners in the Final International University in Kyrenia, the Turkish Republic of Northern Cyprus. Twelve preparatory students were worked with and the data were gathered through interviews and a pronunciation test. The aim of the test was to reveal development and correct pronunciation of th (/ठ/ and $/ \theta /)$ sounds by the participants. The performances of twelve participants were video-recorded to be listened and analysed. Two independent native raters listened to the recordings and rated the problematic sounds as correct or incorrect. After data collection, Microsoft Excel was used to calculate the coded and analysed data, and SPSS (Version 20) was used to find the percentages and the frequencies of the data. The results of the study indicated that language learners could acquire and improve their pronunciation if they feel motivated and were provided with natural opportunities in society. Further, the researchers believe that findings could be useful for both students and language teachers in Northern Cyprus.
\end{abstract}

(C) 2019 JLLS and the Authors - Published by JLLS.

Keywords: Pronunciation problems; EFL learners; mother tongue interference; th (/ð / and / $\theta /)$ sounds; Northern Cyprus

\section{Introduction}

\subsection{Purpose of the Study}

The purpose of the study was to reveal whether preparatory students could improve their problematic th (/ठ/ and $/ \theta /)$ sounds or not by providing authentic opportunities. Twelve preparatory learners from school of foreign languages from FIU were observed and evaluated. The researchers also intended to provide recommendations to develop English pronunciation. Further, they believe that the results will assist lecturers in EFL contexts.

\footnotetext{
${ }^{*}$ Corresponding author. Tel.: +905488515188

E-mail address: halil.ercan@ final.edu.tr
} 


\subsection{Significance of the Study}

Regarding many researches that were conducted on pronunciation problems in the recent literature, this study is believed to contribute to the field with its major focus on how we, as instructors, can provide opportunities for our learners and make them develop their pronunciation skills. Moreover, it will be a proof for them to see the improvement FIU EFL learners in Northern context. Therefore, other learners and teachers from different contexts can reflect on their own learning and teaching processes. In addition to this, the results of this research might also help improve the effectiveness of the programs offered at different universities.

\subsection{Literature review}

Pronunciation has always been a difficult part of a second/foreign language. Many researchers conducted studies on it all over the world. In the area of Turkey, in a study conducted by Şenel (2006), the importance of stress and intonation has been stated for EFL Turkish learners in order to pay attention to correct pronunciation. The study included a practise part and learners had been given instructions to produce correct th (/ठ/ and $/ \theta /$ ) sounds. The learners practised the sounds and developed their pronunciation skills after they had been demonstrated how to position their mouths to be able to produce the correct sounds. They were able to see the differences between $/ \delta /$ and $/ \theta /$, evaluated themselves and got an idea of paying attention to voiced and unvoiced sounds. Gradually, they improved themselves from audio lingual to cognitive perspectives. In another study done by Hişmanoğlu (2007), he pointed out that the Audio Articulation Method (AAM) is an important side of in both teaching and learning a language where EFL/ESL learners can have opportunities to practice their pronunciation skills. Furthermore, he stated the importance of giving learners awareness about uttering the problematic sounds by non-native instructors. He suggested that they can be shown, uttered and demonstrated to them through some diagrams in order to make them improve their pronunciation skills.

On the other hand, Bayraktaroğlu (2008) conducted a study where he focused on isolated sounds, stress and rhythm. He pointed out that instructors of languages need to demonstrate how to utter sounds correctly during the classes. Turkish field is very complicated when it comes to speak and produce the correct sounds for Turkish EFL learners. Karakaş and Sönmez (2011) were able to plan a lesson to teach pronunciation to Turkish EFL learners by using the Audio Articulation Method in which they had opportunities to participate during speaking activities to improve their pronunciation skills. In their planned lesson, their purpose was to teach learners how to overcome their articulation problems regarding th (/ठ/ - / / /) sounds. In addition to this, the similar suggestion was given by Hişmanoğlu (2007) that we as teachers should encourage our learners to make them pick up the correct pronunciation. On the other hand, O'Connor and Fletcher (1989) stated that some of EFL/ESL learners may not have sufficient capacity of hearing the correct pronunciation of the words and, therefore, they may not be able produce the correct sounds. In this case, instructors should deal with these learners and use alternative approaches, methods and techniques in order to give them opportunities to perform their output. Chang (2000) conducted a study to reveal Mandarin Chinese speakers' difficulties with pronouncing $/ \theta /$ and $/$ / sounds. According to results of this study, he stated that the difficulty was due to the lack of $t h$ sounds in Chinese language.

According to Kenworthy (1987), rhythm and stress are more important than intonation as they were gained first by the Japanese learners before intonation. O'Connor (2003) investigated pronunciation problems of Arab learners and came up with many of the pronunciation problems $/ / \mathrm{p} /$ and $/ \mathrm{b} /, / \theta /$ and /ð/). He pointed out that EFL/ESL learners transfer L1 features and it is very difficult to change the 
obtained habits since childhood. Furthermore, he reported it takes a long time and regular practice to overcome these difficulties. Another reason was also stated as the age of learners. In addition to this, he stated that the reason why EFL/ESL learners make pronunciation errors are influenced by sharing different backgrounds and producing the closest sounds.

According to Moosa (1972), there is a conflict between the sound systems of L1 and L2. He stated that Arab learners of English transfer their L1 habits to English language. Therefore, they start to suffer from differentiating particular sounds between L1 and English. On the other hand, Alkhuli (1983) investigated the impact of sound system when learning pronunciation and proved that the main problems were due to the differences between Arabic and English sound systems. Moreover, he pointed out that some sounds such as $/ \theta /$ and $/ ð /$ do not exist in Arabic spoken language but exist in English. Therefore, Arab learners have serious performance problems in producing the correct sounds.

Another significant motive that English learners come up with is that they come from different nationalities and unable to master how to produce the correct sounds for the words in which they are read differently. Therefore, they mainly have failures when they need to guess the correct pronunciation of words in L2.

\subsection{Research questions}

1- Can pronunciation of $t h(/ / /$ and $/ \theta /)$ sounds be improved if opportunities are provided to learners?

2- What is the major difficulty with $t h(/ \partial /$ and $/ \theta /)$ sounds and what can be done to overcome it?

\section{Method}

A questionnaire was used to collect participants' personal information and a pronunciation test was used to elicit whether the EFL learners have improved their pronunciation skills after three months.

\subsection{Participants and Settings}

The study has been conducted in the Final International University, in Kyrenia. There were twelve (8 males and 5 females) school of foreign language learners for this study. They come from different countries and had basic English when they came to the Final International University. They received 25 hours of instruction per week including main course, project \& communication, reading \& writing and listening \& speaking lessons separately from different instructors. One of the researchers was also their instructor to teach them project \& communication lessons and to provide them real life opportunities to make them acquire the language. In four months of teaching, the researcher took them to different cafes, supermarkets, pharmacies, accounting offices, bakeries, banks, streets where they could practise their English. While performing in English, the researcher made them feel comfortable and motivated in order to make sure that they could be confident.

\subsection{Instrument}

The researchers used the pronunciation test to investigate the major pronunciation problems of the participants. Twenty-six items including voiced ( $\circlearrowright$ ) and voiceless $(\theta)$ were aimed to be measured in the present study. The pronunciation test was developed by the researcher himself and supervised by the 
supervisor. All the students were requested to pronounce the words in isolation or in sentences, as well as through the description of pictures, as they were being video-recorded. They were all informed about the study, ethics, and importance of data. The obtained data were listened by two independent native speakers (a female and a male). They were asked to rate the items as correct or incorrect.

\subsection{Data collection procedures}

Twelve participants from the school of foreign languages from the Final International University took part in the study. The researchers applied ethics during the study and got permission from the rector's office in order to conduct their research and video record learners' performances. Besides, the researchers had interviews with the learners after they had informed them about the study. They were asked to pronounce items loudly when being video-recorded. Then, all videos were listened and analysed by two independent judges. They were asked to rate the items as correct and incorrect.

\section{Research Findings}

Firstly, the researchers conducted a Pearson Correlation reliability to ensure and increase the reliability of the research. The result of the test is presented in Table 1 below.

Table 1. Inter-rater reliability.

\begin{tabular}{|ll|r|r|}
\hline & & JUDGE1 & \multicolumn{1}{c|}{ JUDGE2 } \\
\hline \multirow{2}{*}{ JUDGE } & Pearson Correlation & 1 &, $800^{* *}$ \\
1 & Sig. (2-tailed) & &, 000 \\
& $\mathrm{~N}$ & 26 & 26 \\
JUDGE & Pearson Correlation &, $800^{* *}$ & 1 \\
2 & Sig. (2-tailed) &, 000 & \\
& $\mathrm{~N}$ & 26 & 26 \\
\hline
\end{tabular}

**. Correlation is significant at the 0.01 level (2-tailed).

As the table shows above, the test resulted positively and there is a significant correlation between the raters $(\mathrm{r}=0.800, \mathrm{p}<0.01)$.

The frequencies and percentages regarding participants' mispronunciations of consonants are presented in Table 2 below.

ants' mispronunciations of consonants are presented in Table 2 below.

Table 2. Participants' mispronunciations of English consonantal sounds

\begin{tabular}{|c|c|c|c|c|}
\hline \multirow[t]{3}{*}{$\begin{array}{c}\text { Problematic } \\
\text { Consonant }\end{array}$} & \multirow{3}{*}{$\begin{array}{l}\text { Participants' } \\
\text { Mispronunciation }\end{array}$} & \multicolumn{3}{|c|}{$\begin{array}{l}\text { Frequency and Percentage } \\
\text { Judges' assessment }\end{array}$} \\
\hline & & J 1 & \multicolumn{2}{|c|}{ J 2} \\
\hline & & N \% & $\mathbf{N}$ & $\%$ \\
\hline \multirow{2}{*}{$/ \theta /$} & $/ \mathrm{t} /$ & $\begin{array}{|ll|}4 & 15.38 \\
\end{array}$ & 5 & 19.23 \\
\hline & $/ \mathbf{f} /$ & $\begin{array}{|ll|}1 & 3.85 \\
\end{array}$ & 3 & 11.53 \\
\hline \multirow{2}{*}{$/ \mathbf{d} /$} & $|z|$ & - & - & - \\
\hline & $/ \mathrm{d} /$ & $\begin{array}{|ll|}2 & 7.69 \\
\end{array}$ & 6 & 23.07 \\
\hline
\end{tabular}


As shown in Table 4.2 above, only a small number of the learners had problems with the consonants $/ \theta /$ and $/ \delta / . / \theta /$ was he first problematic consonant sound. According to Judge 1, only four participants $(15.38 \%)$ mispronounced it as $/ \mathrm{t} /$, as in the word 'something' which was pronounced as /sımtin/. As for the second Judge, the score was not far and five of the participants (19.23\%) mispronounced the consonant $/ \theta /$ as ' $t$ '. On the other hand, for the first judge only one of the participants $(3.85 \%)$ mispronounced it as ' $\mathrm{f}$ ' as in the word 'think' which was uttered as /fink/.

According to Judge 2, three of the participants (11.53) mispronounced the consonant / $\theta$ / as ' $\mathrm{f}$ ' as in the word 'three' which was pronounced as 'fri'. This indicated that the participants improved their pronunciation skills within their learning process by getting involved into real word situations in the society with the help of the researcher. They seemed to be motivated and had confident while speaking to other people in English. Another problematic consonant sound was /ð/. Only six of the participants (30.76\%) mispronounced it as ' $d$ ' as in the words 'this' which was pronounced as /dis/, 'there' which was pronounced as /der/. This is considered to be due to the fact that students had not been taught how to set their mouth positions to produce the correct sounds. They were thought as they were not aware of this issue to be able to produce correct /ð/ sound as in 'there'. Besides, they did not know what to do during their performances to produce it correctly. However, a great number of the participants were able to produce the correct sounds while having the test. It was satisfactory that they improved themselves in four months by receiving instructors, listening to speakers of English and applying their knowledge outside of their classroom.

\section{Discussion}

The findings of this present research share some common features with other respectful empirical researches such as Hakim (2012), Kwary and Prananingrum (2006), Pal (2013), Field (2003), Ahmadi (2011). As the results clearly revealed, Turkish learners of English had problems with pronouncing the correct English consonants (/ $/ \theta / / \delta /)$ which Turkish language does not have. Therefore, Turkish language learners find it difficult to utter the correct sounds when speaking. However, we as instructors should come up with good teaching techniques and activities in order to match their needs in order to make them speak in the target language. To be able to achieve this goal, we should create some opportunities for our learners to make them have confidence first in order to use the language to communicate with other people.

Similarly, Hakim's (2012) study found that, Java speakers found / $/$ / sound as problematic to pronounce. L1 was considered to be the major matter for them to mispronounce it as /d/, that Turkish language learners have the same problem. In addition to this issue, language education programs for L2 learning makes it even harder to acquire the correct pronunciation skills since many non-native teachers who teach at schools lack to focus on communicative tasks in which pronunciation learning could be included. Thus, many of the English language learners experience difficulties in their real life contexts in which they need to use L2. They have breakdowns in communicating in L2. Once if they do not receive enough listening from other speakers, they will not be able to understand them. Furthermore, language learners could be given and demonstrated weak and strong forms of pronunciation skills. Thus, they may differentiate how to use them correctly in their real lives (Field, 2003).

According to Ahmadi (2011), language teachers should facilitate, observe their learners, and pat attention more on supra-segmental features of English by providing them with a plenty of opportunities to observe outcomes of teaching. Further, he stated that when learners have different opportunities during their learning processes, then they can acquire and perform stress and intonation skills effectively. As a result, it is obvious that a huge number of Turkish EFL learners experience difficulties in 
pronouncing the words correctly since they are not provided with communicative task in which they can enjoy themselves and perform their language skills. It is believed and considered that teachers' role is here to make their learners be aware of the differences between the languages and sound systems of them.

According to Demirezen's (2005) intellectual thought, mother tongue is a major matter for EFL learners that prevents them to produce the correct sounds in English when speaking. Additionally, they do not pay sufficient attention to pronunciation skills since they do not think it is necessary component. Here the issue starts and this usually leads them into unintelligible speeches. As Hebert (2002) stated, both the language learners and language teachers should be aware of the necessity of pronunciation learning and teaching acquiring a foreign language. Otherwise, the learners become unclear during their attempts in the target language.

On the other hand, Varol's (2012) research findings clarified that Turkish adult learners had problems with pronunciations of the correct $/ \theta /, / \mathrm{d} /, / \mathrm{x} / / \mathrm{t} /, / \Re /$ sounds. His study tried to find answers to the influence of their mother tongue sound system when they perform the language. Bada's (2001) research results also revealed the Japanese learners' difficulties in pronouncing sounds such as $/ \theta /, / \mathrm{J} /, / 1 /, / v /$, and $/ r /$. It was reported that these failures were due to their L1 transfer.

In Hong Kong context, Chan (2009) conducted a research to investigate Cantonese learners' pronunciation difficulties. His study revealed they kept repeating the same pronunciation problems although they study the English language for long years. It was believed that this was due to the lack of certain sounds in the Canton language. As for Hakim's (2012) study, Java learners of English were investigated to reveal why they were not able to produce the correct $/ \mathrm{d} /$ and $/ ð /$ sounds. He reported that they had the most serious problem with pronouncing these sounds while learning English.

On the other hand, Baloch (2013) as other scholars who tried to investigate Arabic speakers of English proved his Arabic participants had serious problems with producing the correct consonant sound $/ \mathrm{p} /$. As many of other learners of English, they replaced it with $/ \mathrm{b} /$ sound that exists in their mother tongue. Additionally, Varol (2012), Bada (2001), Keshavarz \& Khamis' (2017) studies also found that their participants had problem with / $/$ and $/ \theta /$. Many of the language learners of English whether they are Arabic, Turkish, Vietnamese or Cantonese mostly came up with similar pronunciation problems and the major reasons were reported that this was due to mother tongue interference, the lack of some sounds, or different sound systems in their L1 and L2.

According to Demirezen's study (2009), it was strongly reported that language teachers of English need to act as models to provide their language learners with the best demonstrations of sounds that do not exist in their mother tongue. One of the important findings of his study revealed that schwa sound has been ignored to be taught and transcribed to its target learners, therefore, the learners missed how to come up with the correct phonetic transcription. Furthermore, Tokoz-Goktepe's (2014) study revealed that Turkish language learners faced difficulties with learning the correct pronunciations of the words. Besides, they pointed out that speaking and pronunciation tasks had not been emphasized by their teachers. Lastly, the study found out that the language teachers believed their learners had anxiety problems as they try to use L2 to perform in front of other learners.

Dung's (2015) study investigated pronunciation problems of Vietnamese learners. The results from this study revealed that Vietnamese participants encountered considerable problems about how to produce correct sounds including stress, intonation, lax vowels, and consonant endings. Both Dung's and this study have similar results as in both Turkish and Vietnam languages the fricatives $/ \boldsymbol{\theta} /$ and $/ \mathbf{d} /$ do not exist. Therefore, it gets even difficult to utter the correct th sounds so they mostly replace $/ \boldsymbol{\theta} /$ and /d/ with /d/, /t/, /f/, /z/. 


\section{Conclusion and Implications}

The present study was designed to reveal development of $t h$ (/ð / and / $/$ /) sounds of EFL learners in the Final International University in Girne, Northern Cyprus. It is believed that English pronunciation is a very important part of second/foreign language learning just as other skills such as reading, writing, grammar and vocabulary are for developing communicative competence in second language learners. As shown in the Tables above, participants came up with less mispronunciation regarding voiced dental fricative (ð) and voiceless dental fricative $(\theta)$ consonants. Most of the participants in this study had no problems with the pronunciation of the consonant sounds $/ \delta /, / \theta /$. Only a small number of them pronounced $/ \delta /$ as $/ \mathrm{d} /$, and $/ \theta /$ as $/ \mathrm{t} /$ and $/ \mathrm{f} /$. They did not know the difference between these two consonants as they did not know how to articulate them correctly at the beginning of the semester, but as they were taught how to produce the correct sounds, they were able to come up with better mouth positioning to produce the correct sounds. Moreover, the researcher believes that it may be due to lecturers of L2 who do not give awareness to their learners of consonants about how to pronounce certain sounds in different ways. Additionally, another reason why many of the participants improved their pronunciation skills may be due to working very hard to provide the best opportunities for EFL learners to make them practice more since English is not spoken around them in Northern Cyprus.

\section{Acknowledgements}

I would like to thank to Assoc. Prof. Dr. Naciye Kunt at Eastern Mediterranean University who inspired me to investigate EFL learners' improvement regarding th sounds and provided insightful comments in each phase of this study.

\section{References}

Alkhuli, M. A. (1983). English as a foreign language. PhD Dissertation, King Abdul Aziz Public Library.

Bayraktaroğlu, S. (2008). Orthographic interference and the teaching of British. pronunciation to Turkish. Learners Journal of Language and Linguistic Studies, 4(2), 19.

Bekleyen, N. (2011). Pronunciation problems of the Turkish EFL learners. Electronic Journal of Social Sciences, 10(36), 094-107.

Demirezen, M. (2007). A model to rehabilitate a fossilized pronunciation error of Turkish English language Teachers: The English consonant phoneme $/ \mathrm{y} /$ wrongly articulated as /nk/ through nasal devoicing. Journal of Language and Linguistic Studies, 3(2), 289-303.

Hişmanoğlu, M. (2007) [๑:] and [ov] contrast as fossilized pronunciation error of Turkish learners of English and solutions to the problem. Journal of Language and Linguistic Studies, 3(1), 99-115.

Karakas, A., \& Sönmez, E. (2011, May). The teaching of [0] and [ð] sounds in English. In 1st International Conference on Foreign Language Teaching and Applied Linguistics (pp. 74-83).

Kenworthy, J. (1987). Teaching English pronunciation. London: Longman.

Şenel, M. (2006). Suggestions for beautifying the pronunciation of EFL learners in Turkey. Journal of Language and Linguistic Studies, 2(1), 111-125.

O’Connor \& Fletcher. (1989). Sounds English, A pronunciation practice book. London: Longman. 
O’Connor, J. D. (1980). Better English pronunciation (2 ${ }^{\text {nd }}$ edition). Cambridge: Cambridge University Press.

Fletcher Ohata, K. (2004). Phonological differences between Japanese and English: Several potentially problematic areas of pronunciation for Japanese ESL/EFL learners. Asian EFL Journal, $6(4)$, article 5.

\section{Appendix A. Pronunciation Test}

\section{Dear Participant,}

Please fill in the following form about yourself and read out loud the words and sentences below. Please note that this is not a test and your responses will be dealt with in purely academic manner and will never be used for any purposes other than the present research.

\section{Thank you for your kind cooperation.}

\section{Background Information}

1. Gender: $\square$ Male $\square$ Female

2. Age:

3. Class:

4. Nationality:

5. Year in North Cyprus:

6. Native Language:

7. Participant's Signature:

\section{Part I. Please read the following sentences aloud.}

1. I am from North Cyprus.

2. The child is so thin.

3. The author wrote his new book.

4. It's always cloudy in southern parts of the country.

5. I think you have something to tell me.

6. He was not honest with me.

7. There is a thick book in my bag. 
Part II. Please read the following words aloud.

\begin{tabular}{|ll|}
\hline 1. & Mother \\
2. & Their \\
3. & This \\
4. & Them \\
5. & Brother \\
6. & These \\
& \\
\hline
\end{tabular}

\begin{tabular}{|ll|}
\hline 1. & Thanks \\
2. & Something \\
3. & Month \\
4. & Thief \\
5. & Clothes \\
6. & Teeth \\
& \\
\hline
\end{tabular}

Part III. Please complete the description of the following pictures and read them aloud.

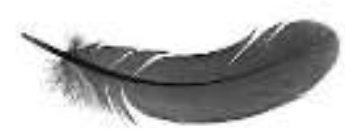

1. This is a $\mathrm{f} . . . . . . . . . . . . .$.

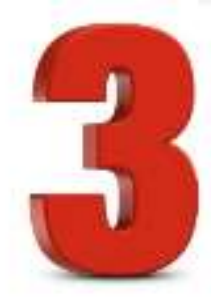

2. This is number t...........

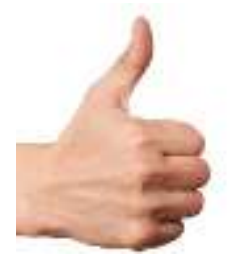

3. It is our $t \ldots \ldots \ldots \ldots \ldots \ldots$

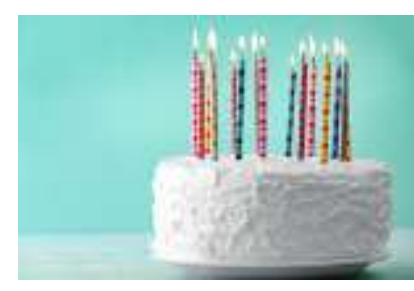

4. What day is it in your life? $B$ 


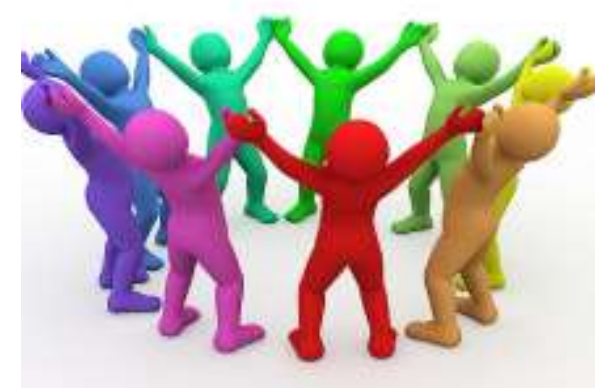

5. They play $t$

İngilizce'yi yabanc1 dil olarak öğrenen öğrenciler için doğru th (/ ð / ve / $\theta$ /) seslerini çıkartmak gerçekten zor mu? Kuzey Kıbrıs'ta bir vaka çalışması.

\section{$\ddot{O} \mathbf{z}$}

Bu çalışma Kuzey Kıbrıs Türk Cumhuriyeti Girne'deki Final Üniversitesi’nde İngilzce'yi yabancı dil olarak öğrenen öğrencilere firsatlar sağlandığında th (/ð/ve / $\theta /)$ seslerinin nasıl iyileştirilebileceğini araştırdı. Çalışmaya on iki hazırlık öğrencisi katılmıştır. Araştırmacılar verileri telaffuz testi ve görüşmeler yoluyla toplamışlardır. Telaffuz testinin amacı katılımcıların th $(/ \partial /$ ve $/ \theta /)$ seslerindeki gelişimini ve doğru telaffuzlarını ortaya koymaktı. On iki katılımının performansları video kayıt olarak kaydedilmiştir. Sonuçların geçerliliğini arttırmak amacıyla alanda uzman ve ana dili İngilizce olan iki kişi (bir kadın, bir erkek) kayıtları dinledi ve sorunlu sesleri doğru veya yanlış olarak değerlendirdi. Veri toplama işleminden sonra, kodlanmış ve analiz edilen verileri hesaplamak için Microsoft Excel kullanılmış ve verilerin yüzdelerini ve sıklıklarını bulmak için ise SPSS (Versiyon 20) kullanılmıştır. Bulgular, yabancı dil öğrenen öğrencilerin kendilerini motive ettikleri ve firsat verildiği takdirde telaffuzlarını edinebileceklerini ve geliştirebileceklerini göstermektedir. Çalışmanın sonuçlarının Kuzey Kıbrıs'ta hem öğrenciler hem de öğretmenler için yararlı olduğu düşünülmektedir.

Anahtar sözcükler: Telaffuz problemleri; İngilizce'yi yabancı dil olarak öğrenen öğrenciler; anadilde girişim; th (/ ð/ ve / $\theta$ /) sesleri; Kuzey Kıbrıs

\section{AUTHOR BIODATA}

1- Halil Ercan is a Senior Instructor in School of Foreign Languages and a Library Director at the Final International University, in Northern Cyprus. He completed his BA in English Language Teaching at the Near East University; MA at the Girne American University; In-service Certification in English Language Teaching ICELT at the Middle East Technical University that held together with the Cambridge University. He is a Ph.D. candidate at Eastern Mediterranean University. His research interests include teaching English to EFL/ESL learners, phonology, phonetics, pragmatics, and teacher education. 
2- Naciye Kunt, is an associate professor of applied linguistics in the Foreign Language Education Department of Eastern Mediterranean University, in North Cyprus. She earned her BA in English Language Teaching, Marmara University, Istanbul, Turkey; MA in TESL \& TEFL and PhD in applied linguistics at the University of Texas at Austin, Austin, TX, USA. Her research interests include learner systems, second/foreign language teacher education, teachers' identities, multilingualism, cultural pedagogies, social justice in TESOL, language learning in conflictual contexts, and young language learners. 